\title{
PLA2G4B wt Allele
}

National Cancer Institute

\section{Source}

National Cancer Institute. PLA2G4B wt Allele. NCI Thesaurus. Code C49367.

Human PLA2G4B wild-type allele is located within 15q11.2-q21.3 and is approximately 20

$\mathrm{kb}$ in length. This allele, which encodes cytosolic phospholipase A2 beta protein, is involved in the calcium-dependent hydrolysis of phosphatidylcholine. 